
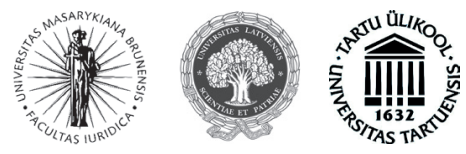

\title{
THE IRANIAN THREAT TO CLOSE THE STRAIT OF HORMUZ: A VIOLATION OF INTERNATIONAL LAW?
}

\author{
Stefan Kirchner \\ University of Lapland, Faculty of Law \\ P. O. Box 122, FI-96101 Rovaniemi, Finland \\ E-mail: stefan.kirchner@humanrightslawyer.eu \\ Telephone: (+358) 4048440012586 \\ Birutè M. Salinaitè \\ University of Lincoln, Lincoln Law School \\ Brayford Pool, LN6 7TS, Lincoln, United Kingdom \\ E-mail: b.salinaite@gmail.com \\ Telephone: +447845020930
}

Received on 27 May, 2013; accepted on 24 August, 2013

doi:10.13165/JUR-13-20-2-10

\begin{abstract}
Along with the Strait of Malacca and the Singapore Straits, the Strait of Hormuz is arguably the most important bottleneck in international navigation because a large part of the global oil production needs to be shipped through this passage, which is only a few kilometers wide. In the context of the dispute about Iran's nuclear program and new sanctions, Iran has threatened to close the Strait of Hormuz for international shipping, effectively cutting off many Western countries from important oil imports. In this article, the legality of such action as well as the legality of the mere threat to close the Strait of Hormuz are investigated. In addition to the International Law of the Sea, general rules of international law and the international law of armed conflict are taken into consideration. Particular emphasis is put on the sovereignty of other states, which is infringed upon by such threats on the part of the Iranian leadership.
\end{abstract}


First, the question has to be answered whether a passage through these waters would be transit passage through a Strait or normal passage through the coastal state's territorial sea. The authors of the article conclude that the regime of transit passage applies qua lex specialis, as far as the part of the Strait of Hormuz, which is included in Iran's territorial waters, is concerned.

The next step is to ask the question whether preventing such a passage as well as threatening to prevent such a passage are permissible for Iran. In this context, the potential abuse of otherwise permitted traffic separation schemes is highlighted. Traffic separation schemes are of particular importance in narrow but highly frequented bodies of water, such as the Strait of Hormuz. In addition, the contemporary Iranian state practice has received some attention. One issue to be considered in more detail is the requirement that foreign warships receive authorization from the coastal state prior to entry into the territorial sea. This approach might be incompatible with the right to innocent passage under both the Law of the Sea Convention and customary international law, as there is no clear legal source, which provides for this requirement.

Finally, the authors look at the question of the legality of the mere threat to close the Strait of Hormuz as opposed to actually closing the Strait. The sovereignty of other states may be affected to such an extent that such threats already amount to a violation of international law. In light of the historic precedents during the Iran-Iraq War, these threats should not be dismissed lightly. Iran would be well advised to refrain from such rhetoric.

Keywords: International Law of the Sea, Territorial Sea, Innocent Passage, Sea Lanes, Strait, Sovereignty, Iran, Hormuz, UAE, Oman, United States of America.

Note: This article only reflects the authors' private opinion.

\section{Introduction}

Since December 2011, the Islamic Republic of Iran has threatened to deny foreign ships the passage through the Strait of Hormuz. Along with the Strait of Malacca and the Singapore Straits, the Strait of Hormuz is arguably the most important bottleneck in international navigation because a large part of the global oil production needs to be shipped through this passage, which is only a few kilometers wide. In fact, closing the Strait of Hormuz would cause significantly more problems for maritime transport than closing the Strait of Malacca or the Singapore Straits because the latter Straits can be circumvented by choosing a longer shipping route, while there is no maritime alternative to the Strait of Hormuz. ${ }^{1}$ Given the global importance of Middle East oil, the West is dependent on Middle East oil in a way, which is unlikely to change anytime

1 Richardson, M. Asia's Middle East Oil Dependence: Chokepoints on a Vital Maritime Supply Line. $1^{\text {st }}$ edition. Singapore: Institute of Southeast Asian Studies, 2007, p. 2 [interactive]. [accessed on 01-24-2012]. $<$ http://www.iseas.edu.sg/tr12007.pdf $>$. 
soon. ${ }^{2}$ Given the strained bilateral relations between the United States and Iran, the conflict is perceived as being between these two states, but it actually affects many more states in the region and beyond. The risk of a dramatically increasing oil price makes this a topic of global interest.

For both the U.S. and Iran, a naval confrontation would not be a first one. Both countries have clashed before during the Tanker War in the 1980s. ${ }^{3}$ While by some perceived as a mere side-show to the first Gulf War (i.e., the 1980-1988 war between Iraq and Iran), the memory of this conflict has been institutionalized on both sides. While the Iranian navy might not be a match for the United States, the Revolutionary Guards (Pasdaran) have a navy of their own, which appears to be preparing for a sort of maritime guerilla warfare ${ }^{4}$ and have in fact harassed U.S. ships in the past. ${ }^{5}$ As of midJanuary 2012, two aircraft carrier groups (Stennis and Vinson) were in the Persian Gulf and the Arabian Sea respectively, while the Lincoln carrier group is thought to be en route from Thailand to the region. ${ }^{6}$

From a military perspective, it would be fairly easy to close the Strait of Hormuz and the Iranian navy has gained extensive experience in the theater already during the war with Iraq in the 1980s. While today Iran's regular navy is engaged far from the shores of the motherland, the Pasadran Navy puts a lot of emphasis on control of the strategically important region. With tensions rising between Iran and the West at the time of writing (January 2012), the question needs to be asked whether not only an actual blockade, but already the mere threat of blocking the Strait of Hormuz - or at least the part of the Strait of Hormuz, which runs through Iranian territorial waters - would amount to a violation of international law on the part of the Islamic Republic. To answer this question, the authors will first look at the legality of a blockade before looking at the legality of the threat to block the strait. By threatening to close the Strait of Hormuz, Iran is not only threatening the United States, but they are in fact holding other states in the region, such as Kuwait and Iraq, as hostages. Therefore, it is necessary to approach the problem from two distinct perspectives, the international law of the sea and general international law.

In this investigation, the authors will leave aside the question of which state has sovereignty over the islands of Tunb as Sughra, Tunb al Kudra and Abu Musa, which are disputed between the Islamic Republic of Iran and the United Arab Emirates (UAE) ${ }^{7}$

2 Burnett, J. S. Dangerous Waters - Modern Piracy and Terror on the High Seas. $2^{\text {nd }}$ edition. Plume, New York and other cities, 2003, p. 28.

3 Haghshenass, F. Iran's Asymmetric Naval Warfare, Policy Focus \#87. The Washington Institute for Near East Policy, 2008, p. 1.

$4 \quad$ Ibid.

5 Pike, J. OPLAN 1019 Arabian Gauntlet. Year [interactive]. [accessed on 01-24-2012]. <http://www.globalsecurity.org/military/ops/arabian-gauntlet.htm>.

$6 \quad$ Ibid.

7 See, for example, Permanent Mission of the United Arab Emirates to the United Nations, Occupation of the Three Islands. Year [interactive]. [accessed on 01-24-2012]. <http://www.un.int/wcm/content/site/uae/ cache/offonce/home/pid/19811;jsessionid=4003333859CAB1EBEB92066E7CE77381>. 
and which are currently occupied by Iran. ${ }^{8}$ Without intending to make any statement on the claims by either Iran or the UAE, the question will be answered if the said islands were part of Iran. At the end of the day, though, while the issue of who has sovereignty of these islands matters for the geographic scope of the problem, the general legal issues will not be affected since part of the sea lanes in the Strait of Hormuz would go through Iran's territorial waters south of Bandar-e-Lengeh in any case, even if Iran had no sovereignty over the said islands.

\section{International Law of the Sea}

\subsection{Iranian Interference in the Strait of Hormuz in Areas under the Jurisdiction of other States}

That Iran may not exercise force in the territorial waters of other states is obvious since this right belongs to the coastal state by virtue of longstanding customary international law and is also enshrined in Article 2 of the United Nations Convention on the Law of the Sea, but Iran may protect itself in the waters off its coast. This is a rather ancient concept: the notion of jurisdiction over the waters immediately adjacent to the land dates back to antiquity, when Rhodes controlled the near waters. This control, though, not only served the purpose of protecting Rhodes, but also the maritime routes around the island, in particular against pirates, a threat which still exists today. Therefore, rights are related to responsibilities and in this regard not much has changed between the Rhodian era of the international law of the sea and today. Jurisdiction may still be based on (albeit no longer limited to) the territory, yet, the territorial sea is not a mere extension, but a part of the territory in this sense, despite existing differences between jurisdiction on land and at sea.

Like a few other states, the Islamic Republic of Iran has signed, but not ratified the 1982 Law of the Sea Convention (LOSC), also known as the Montego Bay Convention.

Any attempt made by the Iranian navy, be it regular navy or Revolutionary Guards, to exercise jurisdiction in the territorial Sea of another state would amount to a serious violation of that state's sovereignty. In fact, the use of military vessels for such purposes, e.g. in UAE or Omani territorial waters, could be considered not only to amount to a violation of Oman's or the UAE's sovereignty, but also as an attempt to limit Oman's political independence, i.e., the capability to exercise jurisdiction free from outside interference. As such, it could amount to a violation of Art. 2 para. 4 of the Charter of the United Nations. While both the UAE and Oman have cordial relations with the United States despite the current political climate, in which some see Oman as attempting to keep the "middle ground" between the U.S. and their Iranian neighbors, the geography makes it more likely that Oman would suffer this fate.

8 Ramazani, R. K. The Persian Gulf and the Strait of Hormuz. Volume 3, $1^{\text {st }}$ edition. Sijthoff \& Noordhoff, Alphen an den Rijn, 1979, p. 72 et seq. 


\subsection{Innocent passage through Iran's territorial sea or transit passage through an international strait}

\subsubsection{The legal nature of the passage in question}

As far as that part of the Strait of Hormuz, which is included in Iran's territorial waters, is concerned, the question has to be answered whether a passage through these waters would be transit passage through a Strait or normal passage through the coastal state's territorial sea. It follows from the lex specialis nature of transit passage that the former applies in such cases. Transit passage may give the navigating state more rights as opposed to regular innocent passage and may thus be more similar to the fundamental principle of the freedom of navigation, but, nevertheless, it is more special in nature than innocent passage. The general rule and the authors' point of departure is the principle of free navigation. Innocent passage is an exception to this general rule, so far as the coastal state's interests are taken into account. Transit passage through territorial waters which happen to be located in an international Strait is an exception to this because it favors the navigating state despite the geographic location. Hence, in such cases the regime of transit passage applies qua lex specialis.

The next step is to ask the question whether preventing such a passage as well as threatening to prevent such a passage are permissible for Iran.

\subsubsection{Transit passage through an international strait}

As a strait, which connects the territorial waters ${ }^{9}$ of coastal states along the Persian Gulf (not only Iran) with the high sea in the Gulf of Oman, and because there is no equivalent alternative to this passage, ${ }^{10}$ a particular legal regime ${ }^{11}$ applies to the waterway in question. Therefore, Articles $34 \mathrm{et} \mathrm{seq.} \mathrm{LOSC} \mathrm{and} \mathrm{the} \mathrm{corresponding} \mathrm{rules}$ of customary international law actually take precedence over the norms dealt with so far under the general rule lex specialis derogat legi generali. This already follows from the omission in Art. $35 \mathrm{LOSC}$ to mention the rules on innocent passage through the territorial sea. Under Art. 38 LOSC, there is a general right to transit passage through Straits, even as far as they include the territorial waters of other states and unlike in the case of regular (i.e. non-Strait) territorial waters, the coastal state has to tolerate not only innocent passage ${ }^{12}$, but also the so called transit passage, which is less restrictive than

9 On the conflicting user demands of the Strait and the territorial sea, see McDougal, M. S. and Burke, W. T. The Public Order of the Oceans: A Contemporary International Law of the Sea. $2^{\text {nd }}$ edition. Dordrecht: New Haven Press, New Haven / Martinus Nijhoff Publishers, 1987, p. 175 et seq.

10 Cf. Graf Vizthum, W..Maritimes Aquitorium und Anschlusszone, in: Graf Vizthum, W. (ed.). Handbuch des Seerechts. $1^{\text {st }}$ edition. Verlag C. H. Beck, Munich, 2006, p. 63 et seq., at p. 141.

11 On the different regimes, see Anderson, D. Modern Law of the Sea, Selected Essays. $1^{\text {st }}$ edition. Leiden: Martinus Nijhoff Publishers, 2008, p. 127 et seq.; on the differences between innocent passage and transit passage, see Schachte, W. L. International Straits and Navigational Freedoms, Remarks Prepared for Presentation to the $26^{\text {th }}$ Law of the Sea Institute Annual Conference. Genoa, Italy, June 22-26, 1992, p. 7 et seq. [interactive]. [accessed on 01-24-2012]. <http://www.state.gov/documents/organization/65946.pdf>.

Art. 45 Law of the Sea Convention (LOSC). 
innocent passage. ${ }^{13}$ Also, under the Straits-regime, Iran may establish sea lanes in its territorial $\mathrm{sea}^{14}$, but it may not - in fact, even less than under the regular territorial sea rules - completely block navigation in its territorial waters. Art. 37 LOSC, which specifies the conditions for this transit passage ${ }^{15}$, is thought by some to reflect the customary law, as it existed before the LOSC. ${ }^{16}$ Even if this view is restricted to international straits of a certain degree of significance for international navigation, ${ }^{17}$ the importance of the Strait of Hormuz for commercial navigation might very well justify the view that as far as this particular strait is concerned the rules which have been codified in Art. 37 LOSC apply to the present situation qua customary international law. This limits Iran's ability to prevent foreign ships from transiting the Iranian territorial sea in the Strait of Hormuz.

\subsubsection{Mandatory traffic separation schemes}

Part of the sea lanes, which connect the Persian Gulf to the Indian Ocean, goes through the territorial sea of the Islamic Republic of Iran. The territorial sea is a maritime zone of no more than 12 nautical miles $(\mathrm{nm})^{18}$ adjacent to the coast and/or baseline which falls under the jurisdiction of the coastal state. Foreign ships have a right to innocent passage through the territorial sea of other states both under Article 17 LOSC and customary international law, provided that the passage is "continuous and expeditious"19 as well as innocent: "Passage is innocent so long as it is not prejudicial to the peace, good order or security of the coastal State." ${ }^{20}$ While foreign warships can claim innocent passage, their passage has long been controversial. ${ }^{21}$ While the United States has signed, but not ratified the LOSC, these restrictions would also apply to U.S. ships by virtue of customary international law. In addition, the United States is a party to the 1958 Convention on the Territorial Sea and the Contiguous Zone (Territorial Sea Convention or TSC), ${ }^{22}$ Art. 14 para. 4 sentence 1, which is identical to Art. 19 para. 1 sentence 1 LOSC. The detailed catalogue included in Art. 19 para. 2 LOSC is not included in Art. 14 TSC, but the 1982 LOSC has given rise to significant state practice ${ }^{23}$, which appears to be based on the necessary opinion juris, indicating "developments [which] are rapidly transforming article 19 of the 1982 Convention into a rule of customary

13 Cf. Art. 38 et seq. LOSC.

14 Art. 41 LOSC.

15 Supra note 10, p. 141.

16 For an overview of scholars who share this view, see Churchill, R. R. and Lowe, A. V. The Law of the Sea. $3^{\text {rd }}$ edition. Manchester: Manchester University Press, 1999, p. 110.

17 Supra note 16, p. 113.

18 The $12 \mathrm{~nm}$ limit, which is codified in Art. 3 LOSC, has gained the status of a rule of customary international law, Christian Gloria, 12. Kapitel: Internationales öffentliches Seerecht, in: Ipsen, K. Völkerrecht. $5^{\text {th }}$ edition. Verlag C. H. Beck, Munich, 2004, p. 816 et seq., at p. 833.

19 Art. 18 para. 2 sentence 1 LOSC.

20 Art. 19 para. 1 sentence 1 LOSC.

21 Supra note 16, p. 88 et seq.

22516 United Nations Treaty Series 205. Year [interactive]. [accessed on 01-24-2012]. <http://untreaty. un.org/ilc/texts/instruments/english/conventions/8_1_1958_territorial_sea.pdf>.

23 For an overview, see supra note 16, pp. 86 et seq. 
law." 24 . Threatening to use armed force against sovereignty or integrity of the coastal state, weapons exercises and espionage against the coastal state and starting or landing aircraft are just some of the activities, which would make passage no longer innocent and hence illegal and both under Art. 25 para. 1 LOSC and under customary law, every coastal state has the right to take measures aimed at preventing illegal and non-innocent passage through its territorial sea. On the other hand, Iran, which also has signed, but not ratified the LOSC, can take measures in the territorial sea to protect its sovereignty, ${ }^{25}$ even though these measures may not prevent innocent passage altogether. ${ }^{26}$ This rule of customary international law is spelled out in more detail in Art. 21 LOSC.

In order to reach countries, e.g. Kuwait, from the Indian Ocean, ships have to use sea lanes through the Strait of Hormuz. Sea lanes, as the name implies, are designated routes of maritime navigation. In particular, they are used in areas, in which a lot of traffic occurs in close geographic proximity, such as straits, and can be imposed by the coastal state ${ }^{27}$ in particular on oil tankers ${ }^{28}$, as far as the coastal state's territorial sea is concerned. The concept of sea lane passage existed in customary international law prior to the adoption of the LOSC, ${ }^{29}$ and, therefore, it is binding also on the two non-parties Iran and the United States, as it is outlined in more detail in Art. 22 LOSC. Legally binding traffic separation schemes have been used for almost half a century in areas, in which a large number of ships have to use a small area of water. ${ }^{30}$ The aspects, which are to be taken into account by the coastal state when delineating sea lanes through its territorial sea, are outlined in Art. 22 para. 3 LOSC, which goes beyond customary law, but takes existing customs into account, such as the "channels customarily used for international navigation". ${ }^{31}$ The considerations included in Art. 22 para. 3 LOSC hint at a more fundamental rule to the effect that the coastal state may not use the right to designate sea lanes for the purpose of blocking the innocent passage through its territorial waters. This is not only a rule of customary law, but already a direct consequence of the prohibition of abus de droit, which follows from the concept of good faith, itself a feature of international treaties for centuries, ${ }^{32}$ and which amounts to a general principle of law ${ }^{33}$ within the meaning of Art. 38 para. 1 lit. (c) of the Statute of the International Court of

\section{Ibid., p. 87.}

25 Art. 25 para. 1 LOSC.

26 Art. 24 para. 1 lit. (a) LOSC.

27 Art. 22 para. 1 LOSC.

28 Art. 22 para. 2 LOSC.

29 Groves, S. Accession to the U.N. Convention on the Law of the Sea Is Unnecessary to Secure U.S. Navigational Rights and Freedoms. The Heritage Foundation, Backgrounder \#2599, 24 August 2011 [interactive]. [accessed on 01-24-2012]. <http://www.heritage.org/research/reports/2011/08/accession-toun-convention-law-of-the-sea-is-unnecessary-to-secure-us-navigational-rights-freedoms $>$.

30 Anderson, D. The Strait of Dover and the Southern North Sea - Some Recent Legal Developments. 7 International Journal of Estuarine and Coastal Law. 1992, p. 85 et seq., at p. 86.

31 Art. 22 para. 3 lit. (b) LOSC.

32 Dahm, G.; Delbrück, J. and Wolfrum, R. Völkerrecht. Vol. I/3, 2 ${ }^{\text {nd }}$ edition. De Gruyter, Berlin, 2002, at p. 845 refer to Art. 1 of the 1659 Pyrenees treaty.

33 Byers, M. Abuse of Rights: An Old Principle, A New Age. 47 McGill Law Journal. 2002, p. 389 et seq., at p. 397 et seq. 
Justice. ${ }^{34}$ That there would be a risk that states would abuse their rights to the detriment of the rights of other states had already been seen by the drafters to the 1982 Law of the Sea Convention, which led to the clarifying Art. 300 LOSC. In fact, for centuries the law of the sea has been tasked with balancing conflicting interests, ${ }^{35}$ one key example being the waters close to shore ${ }^{36}$ which are also the point of interest here. It was the conflict between the Dutch United East India Company, the Vereenigte Oostindische Companie (V.O.C.), and Britain's East India Company (EIC), which gave rise to the landmark work by Hugo Grotius on the freedom of navigation. With his Mare liberum, Grotius defended V.O.C. interests against the EIC in South East Asia. Other examples of the necessary balancing of interests in the creation of new rules of the international law of the sea include the concern for developing states in the exploitation of the natural resources of the deep sea bed (DSB) because the deep sea bed is considered to be a common heritage of mankind. Yet, when the large scale exploitation of the DSB will take off, it will most likely only be a few actors from developed states which will have the technical means to exploit it, which has led to the adoption of special mechanisms under the LOSC for the exploitation of the DSB. ${ }^{37}$

Therefore, so far it can be concluded that the Islamic Republic of Iran may require the use of sea lanes through its territorial waters, but it may not block all access to its territorial waters, let alone the Strait of Hormuz.

\subsection{Contemporary Iranian Practice}

Today, the Islamic Republic of Iran has already required "warships, submarines, nuclear-powered ships and vessels or any other floating objects or vessels carrying nuclear or other dangerous or noxious substances harmful to the environment [to obtain] prior authorization". ${ }^{38}$ From the perspective of the export of oil from the Middle East, this is not as problematic as it may appear to be. Oil might very well be considered a dangerous substance within the meaning of this provision of Iranian law. After all, it has to be noted that no regard is given to the safety measures, which are taken to prevent e.g. an oil spill, but that reference is only made to the substance as such. Yet, it has to be kept in mind that the sea lane, which is located in Iran's territorial waters, i.e. in the northern half of the Strait of Hormuz, is meant for traffic towards the Persian Gulf, while ships carrying oil are to take the southern sea lane through Omani waters.

34 The Statute of the International Court of Justice. Year [interactive]. [accessed on 01-27-2012]. <http:// www.icjcij.org/documents/index.php?p1=4\&p2=2\&p3=0>.

35 Cf. Macrae, L. M. Customary International Law and the United Nation's Law of the Sea Treaty. 13 California Western International Law Journal. 1983, p. 181 et seq., at p. 182 et seq.; for a more modern approach to balancing, see Van Dyke, J. M. Balancing Navigational Freedom with Environmental and Security Concerns. 15 Colorado Journal of International Environmental Law and Policy. 2004, p. 19 et seq.

36 Evans, M. D. The Law of the Sea, in: Evans, M.D. (ed.). International Law. $3^{\text {rd }}$ edition. Oxford: Oxford University Press, 2010, p. 651 et seq., at p. 660.

37 Art. 133 et seq. LOSC.

38 Art. 9 Sentence 1 Act on the Marine Areas of the Islamic Republic of Iran in the Persian Gulf and the Oman Sea. 1993 [interactive]. [accessed on 01-24-2012]. <http://www.un.org/depts/los/LEGISLATIONANDTREATIES/PDFFILES/IRN_1993_Act.pdf $>$. 
A small number of states require foreign warships to receive prior authorization before entering their territorial sea, while many states oppose this restriction. ${ }^{39}$ The requirement of prior authorization by the Iranian authorities, as opposed to a mere notification of the said authorities prior to entering Iran's territorial sea, might be incompatible with the right to innocent passage under both the LOSC and customary international law. ${ }^{40}$ At the very least, there is no rule under customary international law, which allows coastal states to require prior authorization, ${ }^{41}$ least of all of those states, which are persistent objectors. In particular, the United States has held the position that prior consent of the coastal state is needed for transit passage is not necessary. ${ }^{42}$ Transit passage through the territorial sea as far as it is located in a Strait is supposed to be easier than regular innocent passage through the territorial sea. It follows that if the requirement of prior authorisation of passage for foreign warships has no basis in customary law for the territorial sea in general, there is even less of a basis for this requirement in customary law, as it pertains to the passage of straits, which happen to coincide with a state's territorial sea. By demanding prior permission, Iran seems to attempt to turn international law around by $180^{\circ}$, thereby systematically violating the law. Even if one takes into account the Islamic Republic of Iran's fear of foreign military activities close to shore, this violation of the law of the sea is not even necessary from a national security perspective because the LOSC contains explicit rules, which also protect the interests of the coastal state, which has to tolerate transit passage. Rather than violating customary international law, Iran could finally ratify the LOSC. In fact, one might wonder if not the signature of the Convention by Iran might have created a legitimate expectation on the part of other states that Iran also ratify and enforce the Convention in a timely manner.

\section{International Law of Armed Conflict}

To complete the picture, one could also ask if the legal evaluation would change in the event of an armed conflict, e.g., if Iran were to close the Strait of Hormuz in reaction to an attack by foreign forces on Iranian nuclear installations or in the context of the war in Syria, in which Iran is said to be involved significantly. Would it be permissible for Iran to close the Strait if it were a party to an armed conflict?

Exclusion zones, as the one apparently envisaged by the Iranian leadership, are allowed in naval warfare. ${ }^{43}$ However, they are not allowed in peacetime. ${ }^{44} \mathrm{~A}$ rather

\footnotetext{
39 Supra note 21, p. 89.

$40 \quad$ Supra note 10, p. 128.

41 Cf. supra note 16, p. 90.

42 Supra note 11, p. 9; supra note 5.

43 Green, L. C. The Contemporary Law of Armed Conflict. $2^{\text {nd }}$ edition. Manchester: Manchester University Press, 2000, p. 163.

44 On human rights - rather than international humanitarian law - and the law of the sea, see CacciaguidiFahy, S. The Law of the Sea and Human Rights, in: Silverburg, S. R. (ed.). International Law - Contemporary Issues and Future Developments. $1^{\text {st }}$ edition. Boulder: Westview Press, 2011, p. 376 et seq.
} 
recent case of a ship being sunk near an exclusion zone was the case of the Argentinian warship General Belgrano, which was sunk in the Malvinas War. ${ }^{45}$

Unlike anti-personnel land mines, sea mines are legal in principle. ${ }^{46}$ Like all means and methods of war, they are subject to the limitations otherwise imposed on warfare by the ius in bello. ${ }^{47}$ In peacetime, placing unanchored automatic contact sea mines in its own territorial waters is incompatible with international law, hence, placing sea mines into other state's territorial waters, maybe even in a sea lane, is equivalent to firing a shot on a crowded street without looking, making it tantamount to an armed attack against the other state. ${ }^{48}$ In fact, Art. 3 lit. c of the United Nations' General Assembly's Definition of Aggression ${ }^{49}$ states that blocking other state's coast or ports amounts to an act of aggression, which is incompatible with Art. 2 para. 4 UN Charter and which triggers the applicability of the laws of war. While the definition is non-binding, the consent of UN member states to the definition, which "was adopted by consensus", ${ }^{50}$ can be an indicator of the existing customary international law. ${ }^{51}$ If the Islamic Republic of Iran were serious about using all means possible to block the Strait of Hormuz, including the placement of sea mines abroad, it would be on the brink of war not only with the UAE and Oman, but with all states along the coasts of the Persian Gulf, which would be cut off from maritime traffic. These states could resort to armed force as a measure of selfdefense against any such blockade on the part of the Islamic Republic of Iran.

Among the laws of war, the Convention (VIII) relative to the Laying of Automatic Submarine Contact Mines, ${ }^{52}$ commonly referred to as the VIII ${ }^{\text {th }}$ Hague Convention or Hague VIII, dates back to $1907^{53}$ but remains the only international treaty regarding sea mines ${ }^{54}$ and has been taken into account by the ICJ since as late as the $1980 \mathrm{~s} .{ }^{55}$ As far as new types of mines, which were developed after 1907, are concerned, the 1907 Convention is often applied by states to all types of mines, ${ }^{56}$ although this issue appears not to be settled conclusively yet. ${ }^{57}$ The rules of this Convention have long since entered

45 Supra note 43, p. 163.

$46 \quad$ Supra note 43, p. 176.

47 Ibid.

48 The same conclusion is drawn by Cashman, T. M. Striking First...Mine Warfare Goes on the Offensive. 1st edition. Rhode Island, Newport: Naval War College, 2002, p. 13 [interactive]. [accessed on 01-24-2012]. $<$ http://www.dtic.mil/cgi-bin/GetTRDoc?AD=ADA405922>.

49 GA Res. 3314 (XXIX).

50 Brownlie, I. Principles of Public International Law. $7^{\text {th }}$ edition. Oxford: Oxford University Press, 2008, p. 737.

51 Cf. ibid., who considers the Definition to be "a form of State practice" (ibid.).

52 Convention (VIII) relative to the Laying of Automatic Submarine Contact Mines. The Hague, 18 October 1907 [interactive]. [accessed on 01-27-2012]. <http://www.icrc.org/ihl.nsf/FULL/215?OpenDocument>.

53 On the 1907 Second Hague Peace Conference, see Solis, G. D. The Law of Armed Conflict-International Humanitarian Law in War. $1^{\text {st }}$ edition. Cambridge: Cambridge University Press, 2010, p. 53 et seq.

54 Supra note 43, p. 177.

55 Ibid.

56 Cf. Ipsen, K. 16. Kapitel: Bewaffneter Konflikt und Neutralität, in: Ipsen, K. Völkerrecht. $5^{\text {th }}$ edition. Verlag C. H. Beck, Munich, 2004, p. 1195 et seq., at p. 1286. 
into the realm of customary international law. The Convention prohibits the deployment of "unanchored automatic contact mines, except when they are so constructed as to become harmless one hour at most after the person who laid them ceases to control them [and] lay[ing] anchored automatic contact mines which do not become harmless as soon as they have broken loose from their moorings". ${ }^{58}$ In a sense, the VIII ${ }^{\text {th }}$ Hague Convention is characterized by a precautionary principle, which is not uncommon for the international legal instruments of the time, which dealt with new and unknown technologies. Accordingly, "[w] hen anchored automatic contact mines are employed, every possible precaution must be taken for the security of peaceful shipping." ${ }^{59}$ In this context, it has to be kept in mind that murder and ill-treatment of persons on the seas has had a similar status to the same crimes, which were committed against prisoners of war already at the International Military Tribunal in Nuremberg. ${ }^{60}$ Today, the law of maritime warfare receives little attention even from international legal scholars. This is arguably due to a lack in large scale sea battles. The Russo-Georgian war and the final phase of the civil war in Sri Lanka saw sea battles, otherwise conflicts at sea nowadays seem to be skirmishes, such as those between North and South Korea or Japan or the conflicts involving the naval forces of the People's Republic of China (PRC) or the so called People's Liberation Army $\mathrm{Navy}^{61}$ (PLAN), which are associated with the PLAN's extension of China's maritime claims. Nevertheless, it has to be kept in mind that violations of International Humanitarian Law in this regard can also amount to war crimes. ${ }^{62}$ However, Iran's current problem is still one step away from the question whether the planned action is compatible with the laws of war:

Exclusion zones as well as sea mines are only permitted during an armed conflict. At this time, though, there is no international armed conflict between the Islamic Republic of Iran and any other state. ${ }^{63}$ The covert operations said to be taking place in Iran against

58 Art. 1 para. 1 and 2 Hague Convention VIII.

59 Art. 3 Hague Convention VIII.

60 Schabas, W. A. An Introduction to the International Criminal Court. $3^{\text {rd }}$ edition. Cambridge: Cambridge University Press, 2009, p. 113.

61 The name is somewhat misleading since the term "Army" in the Usage of the PRC refers to the armed forces as such. The PLAN is not a sub-unit of the Army in the Western sense of the term, but a branch of the armed forces parallel to the People's Liberation Army Air Force (PLAAF), the ground forces and other more specialized branches. In recent years, the PRC has placed significant emphasis on turning the PLAN into at least a green water navy. Cooper, C. A. The PLA Navy's "New Historic Missions" - Expanding Capabilities for a Re-emergent Maritime Power. 1st edition. Santa Monica: RAND Corporation, 2009, p. 4 [interactive]. [accessed on 01-24-2012]. <http://www.rand.org/pubs/testimonies/2009/RAND_CT332. pdf $>$.

62 On war crimes, see supra note 63, p. 301 et seq.; Zahar, A. and Sluiter, G. International Criminal Law. $1^{\text {st }}$ edition. Oxford: Oxford University Press, 2008, p. 109 et seq.

63 At the time of writing, the fact that some opposition elements are thought to be resorting to armed force have not yet reached a level which would justify assuming the existence of a state of internal armed conflict in Iran, even though an armed conflict requires less than an all-out civil war. Martín, A. M. Conflictos Armados Internos y Derecho Internacional Humanitario. $1^{\text {st }}$ edition. Salamanca: Ediciones Universidad Salamanca, $1990,2^{\text {nd }}$ print: 1999, p. 59. On the distinction between internal and international conflict, see ibid., p. 58 et seq. and p. 60 et seq. 
Iranian nuclear scientists and the Stuxnet attack ${ }^{64}$ do not amount to an armed attack. In peacetime, Iran is not allowed to block the Strait of Hormuz, let alone use mines to do so. In case of an armed conflict, a blockade may be permissible, assuming that it keeps in mind all applicable rules of International Humanitarian Law. In particular the use of mines is highly problematic in this regard.

\section{Intermediate Conclusion}

Therefore, a blockade of the Strait of Hormuz, with or without sea mines, would be illegal at this time.

\section{Mere Threats as Violations of International Law}

\subsection{Sovereignty}

However, it is not only the other coastal states in the region, in particular Oman and the UAE, which have to fear violations of their sovereignty. A state's sovereignty is infringed upon if that state's organs cannot act in a manner, which is free of outside interference. By threatening to close the Strait of Hormuz, oil exporting nations in the region, which can rely on the usability of the Strait for the purpose of exporting oil, now already have to take measures and make plans for the eventuality that Iran should elect to illegally block the Strait for commercial traffic. Such measures could be agreements with third parties concerning the use of pipelines, etc. Effectively forcing a foreign state to take an action, which otherwise it would not have undertaken, limits this state's freedom of action and thereby violates its sovereignty. ${ }^{65}$ This wide view is supported by the ruling of the International Court of Justice in Nicaragua v. United States of America, in which the Court held that:

"The principle of non-intervention involves the right of every sovereign State to conduct its affairs without outside interference; though examples of trespass against this principle are not infrequent, the Court considers that it is part and parcel of customary international law." ${ }^{\prime 66}$

64 On the question whether cyberwarfare constitutes an armed attack, see Kirchner, S. Distributed Denial of Service (DDoS)-Attacks under Public International Law: Responsibility in Cyberwar 8 THE IUP JOURNAL OF CYBER LAW. 2009, nos. 3 \& 4, p. 10 et seq., at p. 17.

65 Kirchner, S.; Alkanli, D. Staatenverantwortlichkeit und Völkerrechtlicher Meeresumweltschutz: Deepwater Horizon. 8 Heidelberg Student Law Review. 2011, p. 215 et seq., at p. 228; see also Kirchner, S. State Responsibility for Transboundary Ecological Damage: The Case of the Amur River Benzole Spill in China, in: Kumari, A. K. (ed.). Water Pollution-Policies and Perspectives. $1^{\text {st }}$ edition. Hyderabad, India: Amicus Books / Icfai University Press, 2007, p. 223 et seq, at p. 231.

66 International Court of Justice. Nicaragua v. United States of America. Judgment of 27 June, 1986, para. 202 . 
Because now their governments need to take actions, which would not be necessary, were it not for the Iranian threat to close the Strait, these states, e.g. Kuwait, have already suffered an infringement of their national sovereignty, which is protected under Art. 2 para. 1 UN Charter. The question which needs to be asked next is whether this infringement actually amounts to a violation of international law. In Nicaragua $v$. United States the, International Court of Justice held that [unfinished sentence].

\subsection{Circumstances Precluding Wrongfulness}

There are also no circumstances, which would preclude the wrongfulness ${ }^{67}$ of this behavior of the Iranian authorities. Iran might claim that the sanctions imposed on the Islamic Republic would give it the right to close the Strait of Hormuz, ${ }^{68}$ yet even if one were to consider today's customary law to reflect only the 1958 TSC (which Iran also signed, but has never ratified ${ }^{69}$ ) rather than the $1982 \operatorname{LOSC}^{70}$ (which was also signed, but has never been ratified by Iran), rather than to assume that today there is a rule of customary international law, which is of equal effect to the transit passage clause of the LOSC, ${ }^{71}$ it has to be noted that also under the TSC, "[p] assage is innocent so long as it is not prejudicial to the peace, good order or security of the coastal State."72 What matters is that it has to be the passage, which provides problems for the coastal state, military or nuclear powered vessels being classical examples, which received attention in the LOSC, as well. Although international law is a whole, in 1958 already, the fragmentation of international law reached a point, at which the law of the sea became for all intents and purposes a self-contained regime. Despite having evolved into a self-contained regime, the international law of the sea has to be understood in its own context, but not in unrelated contexts, such as the existing sanctions against Iran. Any sanctions imposed against Iran have no bearing on the legality of blocking the Strait of Hormuz. Even if the TSC were to apply, it would have to be the passage of the foreign ship in question, which would have to endanger Iran. A denial of the passage cannot be based on issues, which are unrelated to the vessel in question. Iran can neither block the Strait for all foreign ships, nor can the Islamic Republic claim that external factors, which do not pertain to the ships seeking transit passage through the sea lane in its territorial waters, amount to

67 On circumstances precluding wrongfulness, see Crawford, J. and Olleson, S. The Nature and Forms of International Responsibility, in: Evans, M. D. (ed.). International Law. $3^{\text {rd }}$ edition. Oxford: Oxford University Press, 2010, p. 441 et seq, at p. 460 et seq.

68 Cf. Diba, B. A. Is Iran Legally Permitted to Close the Strait of Hormuz? Daily Star. 2012 [interactive]. [accessed on 01-24-2012]. <http:/www.thedailystar.net/newDesign/news-details.php?nid=217263>.

69 On the Status of the Convention on the Territorial Sea and the Contiguous Zone. Year [interactive]. [accessed on 01-27-2011]. <http://treaties.un.org/Pages/ViewDetails.aspx?src=UNTSONLINE\&tabid=2 $\&$ mtdsg_no=XXI-1\&chapter=21\&lang=en\#Participants $>$.

70 On the debate as to which legal regime applies in the Strait of Hormuz, see Simpson, S. Is the Strait of Hormuz Governed by Treaty of by Customary International Law. The View From LL2. 7 January, 2012 [interactive]. [accessed on 01-24-2012]. <http://viewfromll2.com/2012/01/07/is-the-strait-of-hormuz-governed-by-treaty-or-by-customary-international-law/>.

71 Cf. supra note 68.

72 Art. 14 para. 4 sentence 1 Territorial Sae Convention (TSC). 
a justification of its intended actions. Finally, a blockade also cannot be considered a legitimate form of reprisal, since it would necessarily require at least the threat of force. Armed reprisals, though, are outlawed under Art. 2 para. 4 UN Charter. ${ }^{73}$

\subsection{Intermediate Conclusion}

Therefore, the mere threat of closing the Strait of Hormuz has already constituted a violation of International Law to other states in the region, which are economically dependent on the unhindered passage through the strait and which have to ensure that alternative means for the exportation of oil are in place, hence, should the Islamic Republic of Iran realize the threat and close the Strait of Hormuz. So far, the sovereignty of these other states has already been infringed upon because these states have to take actions, such as contingency planning, which they would not have to undertake, were it not for the threat on the part of the regime in Tehran.

\section{Conclusions and Outlook}

Therefore, it can be concluded that it would be illegal for Iran to close the Strait of Hormuz to foreign ships for the purpose of innocent passage. Doing so would amount to a violation of the international law of the sea. In fact, the mere threat to close the Strait of Hormuz and thus to prevent oil exports from countries in the region, such as Kuwait or Iraq, has already amounted to a violation of the sovereignty of these states. The use of the oceans comes with responsibilities not only under the international law of the sea, but also under other aspects of public international law, such as the law of armed conflict ${ }^{74}$ human rights ${ }^{75}$ and general public international law. In threatening to close the Strait of Hormuz, the Iranian leadership might consider such threats to be part of the political game - as often before in the realm of international human rights law, once more, though, Teheran has shown a fundamental failure to comply with international law. The waters of the Western Indian Ocean are already dangerous given the significant pirate threat of the Horn of Africa. ${ }^{76}$ Right now, Iran has already negligently made maritime traffic in the greater region much more dangerous. Given the precedent of Iran's role in the Tanker War, these threats from Teheran have to be taken seriously and should not be dismissed as empty rhetoric. In fact, Iran has been already violating international law by threatening to close this crucial waterway.

73 White, N. and Abass, A. Countermeasures and Sanctions, in: Evans, M. D. (ed.). International Law. $3^{\text {rd }}$ edition. Oxford: Oxford University Press, 2010, p. 531 et seq, at p. 540.

74 Cf. supra note 56, p. 1281 et seq.

75 Supra note 44.

76 Geiß, R. and Petrig, A. Piracy and Armed Robbery at Sea - The Legal Framework for Counter-Piracy Operations in Somalia and the Gulf of Aden. $1^{\text {st }}$ edition. Oxford: Oxford University Press, 2011, p. 6 et seq.; supra note 14, p. 45 et seq. 


\section{References}

Act on the Marine Areas of the Islamic Republic of Iran in the Persian Gulf and the Oman Sea. 1993 [interactive]. [accessed on 01-24-2012]. <http://www.un.org/depts/ 1os/LEGISLATIONANDTREATIES/ PDFFILES/IRN_1993_Act.pdf >.

Anderson, D. Modern Law of the Sea, Selected Essays. $1^{\text {st }}$ edition. Leiden: Martinus Nijhoff Publishers, 2008, p. 127 et seq.

Anderson, D. The Strait of Dover and the Southern North Sea - Some Recent Legal Developments. 7 International Journal of Estuarine and Coastal Law. 1992, p. 85 et seq.

Brownlie, I. Principles of Public International Law. $7^{\text {th }}$ edition. Oxford: Oxford University Press, 2008.

Burnett, J. S. Dangerous Waters - Modern Piracy and Terror on the High Seas. $2^{\text {nd }}$ edition. New York: Plume, 2003.

Byers, M. Abuse of Rights: An Old Principle, A New Age. 47 McGill Law Journal. 2002, p. 389 et seq.

Cacciaguidi-Fahy, S. The Law of the Sea and Human Rights, in: Silverburg, S. R. (ed.). International Law - Contemporary Issues and Future Developments. $1^{\text {st }}$ edition. Boulder: Westview Press, 2011, p. 376 et seq.

Cashman, T. M. Striking First... Mine Warfare Goes on the Offensive. $1^{\text {st }}$ edition. Newport, Rhode Island: Naval War College, 2002 [interactive]. [accessed on 01-24-2012]. <http://www.dtic.mil/cgi-bin/ GetTRDoc?AD=ADA405922>.

Charter of the United Nations. Year [interactive]. [accessed on 01-27-2012]. $<$ http://www.un.org/en/documents/charter/ index.shtml>.

Churchill, R. R. and Lowe, A. V. The Law of the Sea. $3^{\text {rd }}$ edition. Manchester: Manchester University Press, 1999.
Convention (VIII) relative to the Laying of Automatic Submarine Contact Mines. The Hague, 18 October 1907 [interactive]. [accessed on 01-27-2012]. $<$ http://www.icrc. org/ihl.nsf/FULL/215?OpenDocument>.

Cooper, C. A. The PLA Navy's "New Historic Missions" - Expanding Capabilities for a Re-emergent Maritime Power. 1st edition. Santa Monica: RAND Corporation, 2009 [interactive]. [accessed on 01-24-2012] <http://www.rand.org/pubs/ testimonies/2009/RAND_CT332.pdf $>$.

Crawford, J. and Olleson, S. The Nature and Forms of International Responsibility, in: Evans, M. D. (ed.). International Law. $3^{\text {rd }}$ edition. Oxford: Oxford University Press, 2010, p. 441 et seq.

Dahm, G.; Delbrück, J. and Wolfrum, R. Völkerrecht. Vol. I/3, $2^{\text {nd }}$ edition. Berlin: De Gruyter, 2002

Diba, B. A. Is Iran legally permitted to close the Strait of Hormuz? Daily Star. 7 January 2012 [interactive]. [accessed on 01-24-2012]. $<$ http://www.thedailystar.net/newDesign/ news-details.php?nid=217263>.

Evans, M. D. The Law of the Sea, in: Evans, M. D. (ed.). International Law. $3^{\text {rd }}$ edition. Oxford: Oxford University Press, 2010, p. 651 et seq.

Geiß, R. and Petrig, A. Piracy and Armed Robbery at Sea - The Legal Framework for Counter-Piracy Operations in Somalia and the Gulf of Aden. $1^{\text {st }}$ edition. Oxford: Oxford University Press, 2011, p. 6 et seq.

Gloria, C. 12. Kapitel: Internationales öffentliches Seerecht, in: Ipsen, K. Völkerrecht. $5^{\text {th }}$ edition. Munich: Verlag C. H. Beck, 2004, p. 816 et seq.

Green, L. C. The Contemporary Law of Armed Conflict. $2^{\text {nd }}$ edition. Manchester: Manchester University Press, 2000.

Groves, S. Accession to the U.N. Convention on the Law of the Sea Is Unnecessary to Secure 
U.S. Navigational Rights and Freedoms. The Heritage Foundation, Backgrounder \#2599, 24 August 2011 [interactive]. [accessed on 01-24-2012]. <http://www.heritage.org/ research/reports/2011/08/accession-to-unconvention-law-of-the-sea-is-unnecessaryto-secure-us-navigational-rights-freedoms $>$. Haghshenass, F. Iran's Asymmetric Naval Warfare, Policy Focus \#87. The Washington Institute for Near East Policy, 2008.

Status of the United Nations Convention on the Law of the Sea, of the Agreement Relating to the Implementation of Part XI of the Convention and of the Agreement for the Implementation of the Provisions of the Convention Relating to the Conservation and Management of Straddling Fish Stocks and Highly Migratory Fish Stocks. 2013 [interactive]. [accessed on 01-12-2012]. $<$ http://www.un.org/depts/los/reference files/status2010.pdf $>$.

Convention des Nations Unies sur le Droit de la Mer. 1982 [interactive]. [accessed on 01-27-2012]. <http:// treaties.un.org/Pages/showDetails. aspx? objid $=0800000280043 \mathrm{ad} 5>$.

Convention on the Territorial Sea and the Contiguous Zone. Law of the Sea. 1958 [interactive]. [accessed on 01-27-2011]. $<$ http://treaties.un.org/Pages/ViewDetails. asp $\mathrm{x}$ src $=$ UNTSONLINE \& tabid $=2 \& \mathrm{mtd}$ sg_no $=X X I-1 \&$ chapter $=21 \&$ lang $=$ en\#Parti cipants $>$.

International Court of Justice. Nicaragua $v$. United States of America. Judgment of 27 June, 1986.

Ipsen, K. 16. Kapitel: Bewaffneter Konflikt und Neutralität, in: Ipsen, K. Völkerrecht. $5^{\text {th }}$ edition. Munich: Verlag C. H. Beck, 2004, p. 1195 et seq.

Katzman, K. Oman: Reform, Security, and U.S. Policy. Congressional Research Service, 26 August, 2011 [interactive]. [accessed on 01-27-2012]. <http://www.fas.org/sgp/crs/ mideast/RS21534.pdf $>$.
Kirchner, S. Distributed Denial of Service (DDoS) - Attacks under Public International Law: Responsibility in Cyberwar, in: 8 THE IUP JOURNAL OF CYBER LAW. 2009, nos. 3 \& 4,10 et seq.

Kirchner, S. State Responsibility for Transboundary Ecological Damage: The Case of the Amur River Benzole Spill in China, in: Kumari, A. K. (ed.). Water Pollution - Policies and Perspectives. $1^{\text {st }}$ edition. Hyderabad, India: Amicus Books/ Icfai University Press, 2007, p. 223 et seq.

Kirchner, S. and Alkanli, D. Staatenverantwortlichkeit und Völkerrechtlicher Meeresumweltschutz: Deepwater Horizon. 8 Heidelberg Student Law Review. 2011, p. 215 et seq.

Kraska, J. Contemporary Maritime Piracy International Law, Strategy, and Diplomacy at Sea. $1^{\text {st }}$ edition. Santa Barbara: Praeger, 2011.

Law of the Sea Convention. 1833 United Nations Treaty Series I-31363 [interactive]. [accessed on 01-27-2012]. <http://treaties. un.org/doc/Publication/UNTS/Volume $\% 20$ 1833/volume-1833-A-31363-English.pdf>.

Lowe, V. and Staker, C. Jurisdiction, in: Evans, M. D. (ed.). International Law. $3^{\text {rd }}$ edition. Oxford: Oxford University Press, 2010, p. 313 et seq.

Macrae, L. M. Customary International Law and the United Nation's Law of the Sea Treaty. 13 California Western International Law Journal. 1983, p. 181 et seq.

Martín, A. M. Conflictos Armados Internos $y$ Derecho Internacional Humanitario. $1^{\text {st }}$ edition. Salamanca: Ediciones Universidad Salamanca, 1990. 2nd print: 1999.

McDougal, M. S. and Burke, W. T. The Public Order of the Oceans: A Contemporary International Law of the Sea. $2^{\text {nd }}$ edition. New Haven: New Haven Press/Dordrecht: Martinus Nijhoff Publishers, 1987, p. 175 et seq.

Permanent Mission of the United Arab Emirates to the United Nations, Occupation of the 
Three Islands. Year [interactive]. [accessed on 01-24-2012]. <http://www.un.int/wcm/ content/site/uae/cache/offonce/home/pid/19 811; jsessionid $=4003333859$ CAB1EBEB92 066E7CE77381>.

Pike, J. OPLAN 1019 Arabian Gauntlet. Year [interactive]. [accessed on 01-24-2012]. $<$ http://www.globalsecurity.org/military/ ops/arabian-gauntlet.htm>.

Pyrenees Treaty. 1659.

Ramazani, R. K. The Persian Gulf and the Strait of Hormuz. Vol. 3, $1^{\text {st }}$ edition. Alphen aan den Rijn: Sijthoff \& Noordhoff, 1979, p. 72 et seq.

Richardson, M. Asia's Middle East Oil Dependence: Chokepoints on a Vital Maritime Supply Line. 1 Trends in Southeast Asia Series. 1st edition. Singapore: Institute of Southeast Asian Studies, 2007 [interactive]. [accessed on 01-24-2012]. $<$ http://www.iseas.edu.sg/tr12007.pdf> (last visited 24 January 2012).

Schabas, W. A. An Introduction to the International Criminal Court. $3^{\text {rd }}$ edition. Cambridge: Cambridge University Press, 2007. $3^{\text {rd }}$ printing: 2009.

Jr., Schachte, W. L. International Straits and Navigational Freedoms, Remarks prepared for presentation to the $26^{\text {th }}$ Law of the Sea Institute Annual Conference. Genoa, Italy, June 22-26, 1992, p. 7 et seq. [interactive]. [accessed on 01-24-2012]. <http://www.state. gov/documents/organization/65946.pdf $>$.

Jr., Schachte, W. L. The History of the Territorial Sea from a National Security Perspective. 1 Territorial Sea Journal. 1990-1991, p. 143 et seq.

Simpson, S. Is the Strait of Hormuz Governed by Treaty of by Customary International Law. The View From LL2. 7 January, 2012 [interactive]. [accessed on 01-24-2012].
$<$ http://viewfromll2.com/2012/01/07/is-thestrait-of-hormuz-governed-by-treaty-or-bycustomary-international-law/>.

Solis, G. D. The Law of Armed Conflict International Humanitarian Law in War. $1^{\text {st }}$ edition. Cambridge: Cambridge University Press, 2010.

Statute of the International Court of Justice. Year [interactive]. [accessed on 01-272012]. <http://www.icj-cij.org/documents/ index.php?p1 $=4 \& \mathrm{p} 2=2 \& \mathrm{p} 3=0>$.

Territorial Sea Convention. 516 United Nations Treaty Series 205. Year [interactive]. [accessed on 01-24-2012]. <http://untreaty. un.org/ilc/texts/instruments/english/ conventions/8_1_1958_territorial_sea.pdf $>$.

United Nations General Assembly, GA Res. 3314 (XXIX).

Van Dyke, J. M. Balancing Navigational Freedom with Environmental and Security Concerns. 15 Colorado Journal of International Environmental Law and Policy. 2004, p. 19 et seq.

Vizthum, W. G. Begriff, Geschichte und Rechtsquellen des Seerechts, in: Vizthum, W. G. (ed.). Handbuch des Seerechts. $1^{\text {st }}$ edition. Munich: Verlag C. H. Beck, 2006, p. 1 et seq.

Vizthum, W. G. Maritimes Aquitorium und Anschlusszone, in: Vizthum, W. G. (ed.). Handbuch des Seerechts. $1^{\text {st }}$ edition. Munich: Verlag C. H. Beck, 2006, p. 63 et seq.

White, N. and Abass, A. Countermeasures and Sanctions, in: Evans, M. D. (ed.). International Law. $3^{\text {rd }}$ edition. Oxford: Oxford University Press, 2010, p. 531 et seq. Zahar, A. and Sluiter, G. International Criminal Law. $1^{\text {st }}$ edition. Oxford: Oxford University Press, 2008. 


\title{
IRANO GRASINIMAS UŽDARYTI ORMŪZO SĄSIAURI: TARPTAUTINĖS TEISĖS PAŽEIDIMAS?
}

\author{
Stefan Kirchner \\ Laplandijos universitetas, Suomija \\ Birutè M. Salinaitè \\ Lincolno universitetas, Jungtinė Karalystė
}

Santrauka. Greta Malakos ir Singapüro sąsiauriu, Ormüzo sasiauris yra, be abejonès, svarbiausias kelio susiaurejimas tarptautinejje laivyboje, nes didele dalis pasaulinés gamybos naftos turi büti gabenama per šz pasaža, kuris yra tik keliu kilometru pločio. Nesiliaujant ginčams dèl Irano branduolinès programos ir naujų sankciju, Iranas grasino uždaryti Ormūzo sąsiaurị tarptautiniam gabenimui, šitaip atkirsdamas dangelị Vakaru šalių nuo svarbaus naftos importo. Šiame straipsnyje tiriamas tokio veiksmo, taip pat ir grasinimo uždaryti sasiaurị teisètumas. Be to, atsižvelgta ì tarptautines jüru teisés, bendrosios tarptantinés teisès ir tarptautines ginkluoto konflikto teises taisykles.

Visu pirma turi büti atsakyta, ar pasažas per šituos vandenis bütu tranzitinis pasažas per sasiauri, ar normalus pasažas per pakrantès valstybès teritorine jürą. Galime daryti išvadą, kad tranzitinio pasažo režimas taikomas qua lex specialis Ormüzo sąsiaurio daliai, kuri yra įtraukta i Irano teritorinius vandenis.

Kitas klausimas, ar sutrukdymas tokiam pasažui, kaip ir grasinimas sutrukdyti tokiam pasažui, leistinas Iranui. Atsižvelgiant iz tai pabrěžtas potencialus piktnaudžiavimas leistinais eismo ribojimo planais. Eismo ribojimo planai turi tam tikra reikšme siauruose, bet labai dažnai lankomuose vandens telkiniuose, tokiuose kaip Ormūzo sasiauris. Be to, i šsiuolaikine iraniečiu valstybine praktika buvo atkreiptas demesys. Viena svarstomu problemu yra reikalavimas, kad užsienio karo laivai prieš iplaukdami i teritorine jüra iš pakrantes valstybès gautu leidimą. Ši tvarka galetu büti nesuderinama su teise i nekalta pasaža pagal Jüru teisès konvenciją ir iprastą tarptautinę teisę, kadangi nèra jokio aiškaus teisèto šaltinio, kuris numato ši reikalavima.

Galiausiai, autoriai svarsto šz klausima dèl paprasčiausios grèsmès uždaryti Ormüzo sasiauri teisètumo, o ne, tiesq sakant, dèl sasiaurio uždarymo. Kitu valstybiu aukščiausioji valdžia gali büti paveikta tokiu mastu, kad tokie grasinimai jau pasieks tarptautinès teisès pažeidimo lygi. Prisimenant istorinius Irano-Irako karo precedentus, šie grasinimai neturi büti lengvai atmesti. Iranui būtu geriau susilaikyti nuo tokios retorikos.

Reikšminiai žodžiai: tarptautine jūru teisè, teritorinè jūra, nekaltas pasažas, jūru juostos, sąsiauris, aukščiausioji valdžia, Iranas, Ormüzas, Jungtiniai Arabų Emiratai, Omanas, Jungtines Amerikos Valstijos.

Pastaba. Šis straipsnis atspindi tiktai asmenine autoriu nuomonę. 
Stefan Kirchner, Laplandijos universiteto (Rovaniemi, Suomija) vizituojantis profesorius, daktaras. Mokslinių tyrimų kryptys: tarptautinè viešoji teisè, žmogaus teisių apsauga, teisè ir globalizacija, tarptautinè jūrų teisè.

Stefan Kirchner, University of Lapland (Rovaniemi, Finland) visiting professor, doctor. Research interests: Public International Law, Human Rights, Law and Globalization, International Law of the Sea.

Birutė M. Salinaitė, teisès studendė Linkolno universitete, Didžioji Britanija. Mokslinių tyrimų kryptys: tarptautinè teisè, tarptautinè jūrų teisè, korporacijų ir komercinè teisè.

Birutė M. Salinaitè is a Law Student at the University of Lincoln, Lincoln, the United Kingdom. Research interests are international law, the international law of the sea, corporate and commercial law. 